\title{
Can the Discreditable be an Advantage? Mental Illnesses as Metaphors on Rhetorical Usages for Language Teaching
}

\author{
Yu-Chun Shih, Shu-Chuan Chen*
}

Department of Foreign Languages and Literature, Asia University, No.500, Liufeng Rd., Wufeng, Taichung, Taiwan

\section{A B S T R A C T}

\begin{abstract}
Mental illnesses often inspire artists and writers and are omnipresent in various works, yet the moral adequacy of portraying their images remained controversial: Erving Goffman (2010) had described the challenges the "discreditables" might have faced and the privileges they might get once being uncovered in his essay. However, Susan Sontag believed that wrapping disease in metaphors discouraged, silenced, and shamed patients in her Illness as Metaphor. This paper aims to center the discussion on what the diseases and the patients will represent and the privileges be demonstrated in these texts from a rhetorical aspect? By applying principally the theories of uncanny, abjection, and stigma, this paper has built a theory on presuming Meursault in Camus's The Stranger has Asperger, then analyze the power of stigma in two recent works: the episode "ADHD Is Necessary" in Taiwanese TV drama: On Children, and a French novel: Nothing Holds Back the Night. The results showed that the mental illness can be an advantageous and necessary metaphor, just as an endowing "Mark of Cain", threatening yet defensive. Meanwhile, the mental illness as metaphor can be applicable in language teaching.
\end{abstract}

\author{
A R T I C L E I N F O
}

\author{
Paper type: \\ Research Article \\ Article history: \\ Keywords: \\ - Discreditable \\ - Mental illnes \\ - Abejection \\ - Autism \\ - Stigma
}

Received: 27 February 2019

Revised: 16 April 2019

Accepted: 16 April 2019

- Rhetoric

\section{Introduction}

It is commonly known that minority is often neglected or muted by the dominant hegemony, thus, as we can effortlessly observe, the paroles and doctrines are controlled strictly by the labeled-center group. Consequently, the avail of being situated at the margin is relatively overlooked. Chen and Fang's research probing the foreign brides has demonstrated how three variant types of narratives, constructed by the frequently slandered new residents in Taiwan, can portray the panorama holistically and realistically without effacing the shadows, simply because the authentic somberness is pervasive within their reach. Further, they have also accentuated the silence of these new Taiwanese mothers by appropriating the medical term "aphasia".

From a linguistic point of view, when we juxtapose a disease, in this case, aphasia, with a perceived marginal group, it could allude an unsolicited defect, or evoke uneasiness. Likewise, Sontag posited the deleterious nature under certain embellished façades of pathology-inspired fantasies. Thus, in the context of SLA, Brown has underlined the significance of cultural influences embedded in the language, and he has concluded that the lexical options are the primal ingredients pivotal to the nurturance of language ego. According to the notions above, we could deduce that the labels, either imposed by others or advanced by ourselves, can contribute an immense, and mutual impact to social stratification. To be precise, while our cultural identities are multideterminant (Brown, 2014), the lexis we opted to equate with ourselves or others can be manipulated craftily or maneuvered deviously. Moreover, we may postulate that even if one lexis can be interpreted and applied in one

\footnotetext{
* Corresponding Author. Associate Professor, Department of Foreign Languages and Literature, Asia University.

E-mail addresses: yuchun.shih@mail.com (Y.-C. Shih), csc71@asia.edu.tw (S.-C. Chen).

doi: https://doi.org/10.14710/parole.v9i1.31-43
} 
way, it is still probable to interpret it in a contrary manner. For instance, Goffman (2010) indicated that the "discreditables" have the tendency to filter the settings, interlocutors and discourses to consider whether they should unveil their disguised uniqueness. If the disclosure of some discrepancies in banality is sometimes worthwhile and preferable, we could now endorse the employment of seemingly pejorative rhetoric in a supportive argument. Simultaneously, a YouTube music video made by Taiwanese doctors has uncloaked the symptoms of urinary disorder and attracted the attention of the public and the press (Li \& Lai, 2008; Liao, 2019; Lu, 2019). In France, Lomepal's song disclosing the insanity in the family has also taken off (Narlian, 2018), particularly, one of his popular song The Beautiful Madeness "s pre-chorus is "The regular people feel good in the machine / Grandma never found her place in there (her place)" (Valentinelli \& Lomepal, 2018)2. Their triumph might signify an alternative perspective that the mass can alter toward the extraordinariness.

The current study aims to inquire the emblems of mental disorders, notably ASD, ADHD, and bipolar disorder, in contemporary Taiwanese TV drama and French literature. The principal instruments to underpin the research consist of Erving Goffman's stigma, Sigmund Freud's uncanny, and Julia Kristeva's abjection. The result vindicated Goffman's insightful scheme that when the "discreditable" finally ceased lurking from the darksome, their singularity could become advantageous, necessary, and even be of precious qualities.

\section{Theories}

Deleuze and Guattari argued that the minor literature has the feature of minor characteristic manifested in dominant languages. They further added that the aforementioned feature itself could also be seen as an impulsive force that embodies one's eagerness to restructure the present status of the "superior" language. Johnson, on the other hand, once remarked that Camus's work The Stranger could be interpreted by Bergson's humor theory, since the protagonist Meursault was able to perceive the syntactic rules while precluding its inner meanings simultaneously. Similarly, he reinforced that Meursault's unconcerned attitude can even perpetrate a revolt against the monotonous routine through his alien-like behavior caused by a misplacement of emotion, which is usually incoherent and inadequate under the actual sociocultural context (Johnson, 1973). However, Johnson's paper has concluded that The Stranger failed to be recognized as a comical work for because the theory only functions when the minority and the repugnance are the ones to be synchronized.

To sum up the foregoing ideas, it may seem that an alien and minor syntax, or conduct of individuals might: (1) Incite the public's uneasiness instead of assurance, and (2) Instigate a riot which leads to a change. Yet, on the contrary, it is also possible that: (1) The dread, and the trepidation were not to the minor others, but to the majority's inner self; (2) The fear were inherently the "uncanny" feeling, calling for abjection, yet restrained by social norms; (3) The act of flouting rules is acceptable, but it consists of a rare privilege often exclusively possessed by radical eerie minorities, which would break the harmony intentionally or unintentionally by their mere presence.

\subsection{Meursault and Asperger Syndrome}

Ensuing the supposition above, we may begin with some presences of the incoherent notes occurred in Camus's The Stranger ${ }^{3}$. First, semantically meaningless notes could be comical and are common mistakes: Do pet words and frequently used lexis contain semantic meanings? Or do they sometimes mean nothing? Johnson stated that the characters in The Stranger suggest some humorous effect since they persistently articulated vacant-meaning phrases. Plus, by comparing Meursault's perceived hilarious conduct with the minor characters in the book, he observed that the protagonist wasn't the only one who conducted the error. Second, proficient notes in misplacement suggest tension and are rarely awarded: McCarthy has noticed that Meursault wasn't fully agreed with the lexical choice on the telegram. Not only because it has applied implicit time deixis and led to confusion, but its distant, formal, and robotic format might also be a part of the reason. However, he further pointed out that, contradictorily, Meursault himself has also made a similar mistake by retaining a habitual appellation when referring his mother, as if unaware of any special event. Last, Bum notes which are obstinate and failed to regulate might be mortal: If Meursault is not the one and only person in the book that has committed the crime of violating the linguistic rule yet is the one who ended up sitting alone in the prison and pondering

\footnotetext{
${ }^{1}$ Original name: "Beau la folie". English translation by the first author of the paper.

${ }^{2}$ Original lyric: "Les gens normaux se sentent bien dans la machine / Grand-mère n'y a jamais trouvé sa place (her place)". English translation by the first author of the paper.

${ }^{3}$ The citations of the novel are translated directly from the original French version by the first author of the paper.
} 
"...hoping that there will be a huge crowd of spectators receiving me with roars of hatred in the day of my execution, so that I'll feel less alone" (Camus, 2005) ${ }^{4}$, there might be some reasons. We can see that he turned the priest down more than once and rejected any interventions in the story, "I have refused to receipt the priest for the third time. I have nothing to say to him, I don't want to talk anymore... The only thing that I have interest in now, is to escape from the mechanism, to see if the doomed certainty could encounter some mistakes" $(\text { Camus, 2005) })^{5}$, it appeared that he lost the desire to converse, and thus, might not be expecting any potentially optimistic hope from another conversation. This line also seemed to imply that he was still looking for the possibility for reversing the situation, or the fate, but did not approve that the change will be relied upon any talk.

Followed by the assumption of stubborn and fatal bum notes, another crucial question to be solved is: Does Meursault have emotions? From the contents cited above (Camus, 2005) it seems rather pertinent to say that he does has the capacity to sense the loneliness. Contrary to McCarthy's argument, the fact that Meursault has opted the word "mom" (Camus, 2005) ${ }^{6}$, over "mother" (McCarthy, 2004) in his monologue could be interpreted as a gesture justifying a degree of attachment and intimacy. Johnson stated that the telegram on the very first page of The Stranger is self-contradictory because the speaker does not engage any adequate, and authentic emotion in the formula. Nonetheless, simply based on the brief telegram, it is possible to refute his point, since McCarthy had pointed out that "passed away" (Camus, 2005) $)^{7}$ consists of a moderated lexical choice. Therefore, we may vindicate that the sender of the telegram did have emotion, or sympathy, but might have faced a dilemma between following the standard format without any obvious engagement of personal sentiment and trying to utter contrarily, in a gentler way. We may estimate that the sender's act of closing the telegram by official format could be regarded as an adaption to the socio-cultural context, and yet, still contains meaning rather than being a pure mechanic. This closure might sound unfit to the content of condole either because it consists of an element of politeness formulas or an expressive speech act.

Ferguson's article on politeness formulas has indicated that a paucity of explicit and profound demonstration on the sematic scheme were valued even in L1 learning context, and learners might reside in this caco-gastric state unchangingly unless they eventually fully absorb them and hence capable for the succeeding transformation process. Further, in speech act theory, Searle (1976) stated that the expressive acts are used to convey one's inner responses, but in some way will not correspond to the linguistic background structure unless the issue that stimulated this feeling is regarded as a triggering object. Therefore, we may consider that the sender of the telegram might have simply effectuated a linguistic error that anyone could have made. And back to Meursault, although those two points above could reinforce what we can already deduced from Johnson's argument that he might have problem internalizing the semantic meaning behind the lexis and therefore utterances and actions both seemed to be meaningless to him. We can still presume that Meursault does have feelings but does not have the ability to express logically and distinguish between regular situations and incidents, hence he has expressed discordant emotion in certain events. Concluding the data, an epiphany seems to come across: if Meursault has emotion, but has more trouble reading the $\operatorname{air}^{8}$ than most regular people, may we interpret that he has the symptoms of Asperger's? If this supposition is valid, Meursault's uncompromising stand against the talk ${ }^{9}$ will not surprise us no more since he has always been talking in standard manner e.g. "It's not my fault" (Camus, 2005) ${ }^{10}$ and witnessing other doing so, e.g. "Best regards" (Camus, 2005) ${ }^{11}$. Therefore, it goes without saying that he could be confused about why he has irritated people through his words. Another critical evidence is that: as Celeste has sorrowfully mentioned to him "We only have one mother" (Camus, 2005) $)^{12}$, which suggests Meursault should have reacted abnormally and not "...as always" (Camus, $2005)^{13}$ like he usually does, after acknowledging the loss of an irreplaceable existence. He just felt ".... a little bit dizzy..." (Camus, 2005) ${ }^{14}$, since he was absentmindedly thinking about one formula of funeral: wearing

\footnotetext{
${ }^{4}$ Original text: “...pour que je me sente moins seul, il me restait à souhaiter qu'il y ait beaucoup de spectateurs le jour de mon execution et qu'ils m'accueillent avec des cris de haine."

${ }^{5}$ Original text: "Pour la troisième fois, j'ai refusé de recevoir l'aumônier. Je n'ai rien à lui dire, je n'ai pas envie de parler... Ce qui m'intéresse en ce moment, c'est d'échapper à la mécanique, de savoir si l'inévitable peut avoir une issue."

${ }^{6}$ Original text: "maman"

7 Original text: "décédée"

${ }^{8}$ Japanese expression: it means the ability to understand the situation by reading others' countenances as well as utterances and behave appropriately.

${ }^{9}$ Camus, 2005 p.107

${ }^{10}$ Original text: "«Ce n'est pas de ma faute.»"

11 Original text: "Sentiments distingués."

12 Original text: "«On n'a qu'une mère.»"

13 Original text: "...comme d'habitude"

14 Original text: "...un peu étourdi..."
} 
formal costume "... one black tie and an armband" (Camus, 2005) ${ }^{15}$, which is apparently another shallow, visible rule he may had perceived demonstrated by others "...he has lost his uncle several months ago" (Camus, $2005)^{16}$.

From the evidences above, we can now speculate that Meursault has some clinical characteristic of Asperger. In a laconic manner, the indications include: prominent capacity in retaining the identical contents, intense persistence in circulating monotonous and inflexible behavior, the solitude, inability in comprehension of normative illocutionary act and gestural implication, demonstrating limited feedbacks, self-centered dialogue style (DSM IV 80-81). And according to DSM- $5^{17}$, the critical features of ASD are: repetitions of non-verbal and verbal rituals, difficulties in expressing affections and succeeding socializations, plus, extraordinary responses to external stimulation. Since the other principles are obvious from the previous analysis, we may construe the last criteria as an explanation to Meursault's intolerance of sunlight. In The Stranger, Meursault's irritation at sunlight has consistently continued throughout the text then peaked and overlapped the climax of the plot:

I waited. The burning heat of the sunlight kept hounding my cheeks and I could feel the sweat gathering in my eyebrows. It was the same sunlight the day I when I attended the burial of my mother, and, just like then, my forehead hurt extremely, all the vessels were beating under the skin. Because of this insufferable sunlight, I made a pace forward ${ }^{18}$.

I shook off the sweat and the sunlight. I knew that I hat destructed the balance of the day, and the perfect silence of the beach where I was happy. Then, I pulled the trigger again, shot the inert body four extra times... ${ }^{19}$.

Seemingly apathetic, Meursault's commencement of a new relationship with Marie right after the day of the burial (Camus, 2005), accumulated with his unawareness and incomprehension of funerary rites during the day of the wake (Camus, 2005), eventually added the death of the Arabian (Camus, 2005), which was the last straw, has incited the rage of the masses. Nevertheless, besides the fury, there may be feelings of other natures, of which this paper seeks to investigate closely by applying the theory of uncanny and abjection, but before that, we may first probe into the stigma of psychical impairments.

\subsection{Stigma and Mental Illness}

For Sontag, one criterion that distinguishes the infections of lungs from the cancer and affects people's aspect of them rests on where they nest.

If the image of lungs is more positive and mental, it seems that another infamous disease has the tendency to be rather physical, and is often attach with the organs that we would often prefer to conceal in a dialogue:

While TB takes on qualities assigned to the lungs, which are part of the upper, spiritualized body, cancer is notorious for attacking parts of the body (colon, bladder, rectum, breast, cervix, prostate, testicles) that are embarrassing to acknowledge. (Sontag, 2002)

A disease of the lungs is, metaphorically, a disease of the soul. Cancer, as a disease that can strike anywhere, is a disease of the body. Far from revealing anything spiritual, it reveals that the body is, all too woefully, just the body. (Sontag, 2002)

\footnotetext{
${ }^{15}$ Original text: “...une cravate noire et un brassard.”

${ }^{16}$ Original text: "...il a perdu son oncle, il y a quelques mois."

${ }_{17}$ Once distinct from other autism symptom in DSM-IV, Asperger syndrome is now diagnosed as a part of ASD (Autism Spectrum Disorder), in DSM-5 (DSM-5 51).

${ }^{18}$ Original text: J'ai attendu. La brûlure du soleil gagnait mes joues et j'ai senti des gouttes de sueur s'amasser dans mes sourcils. C'était le même soleil que le jour où j'avais enterré maman et, comme alors, le front surtout me faisait mal et toutes ses veines battaient sous la peau. À cause de cette brûlure que je ne pouvais plus supporter, j'ai fait un mouvement en avant.

${ }^{19}$ Original text: J'ai secoué la sueur et le soleil. J'ai compris que j'avais détruit l'équilibre du jour, le silence exceptionnel d'une plage où j'avais été heureux. Alors, j'ai tiré encore quatre fois sur un corps inerte... (64)
} 
Consequently, she pointed out that both diseases could evoke the towpath to the Hades, yet the journey leaded by a cancer seems to be a less idyllic one (Sontag, 2002). And she deduced that it is the nature of the stranglehold, counted more significantly than the infection itself that empowers the uninfected group to acquire a sense of superiority. As she further explicated, from a psychical aspect, the patients are to blame because the illness is the fruit of their inward aspiration, and for earlier dogmas, the discomforts in body are the betrayers of mental discipline. Intriguingly, Sontag also stated that the characteristic of Meursault, pictured barely ardent, is in accord with that of a cancer kind: "... restless, bitter, self-destructive, tormented by their inability to feel", and that, those who carry this disease are likely to face solitude.

If we sum up Sontag's thesis, the image of cancer is more likely to be a degraded one since it alludes that there must be some secret desire, buried profoundly by the patient, yet embodied by physical suffering, automatically without getting any sanction for it. Notably, it appears that the organs that concerned could often be either reproductive or excretory, this may imply that the covert impulsion may be traced back to the sin of lust. Moreover, Sontag mentioned the application of the term "invade" when describing cancer. It seems to articulate that the preserved desire may lose control and may take over the body step by step. And the individuals conquered by this disease may end up in exile.

While Sontag has classified Meursault's character as cancer type, the current article aims to rearrange it for ASD type. Together with tuberculous, it is believed that the causation of mental disease consists of intense affection or repression (Sontag, 2002). Withal, for physical illness, the restricted intention become tangible through reflecting on the body (Sontag, 2002), however, for psychical impairment, it seems to take a more abstract form. Take Asperger syndrome for instance, one may barely observe mild indication or subtle incoherence in a conversation. Opposite to physical illness, a raconteur, mental illness such as Asperger syndrome seems to possess a taciturn personality and be the soul of discretion. The affections are constricted and muted, therefore the patients could sometimes appear to be callous. The diagnosis also gives a more obscure impression than that of a concrete illness.

Assuming that the demonstration of will could become tricky and deceitful, the impulsion could thus become imperceptible. In contrary to the cancer, which uses portentous physical pains to divulge the desire ultimately in the last phase of life, the Asperger syndrome opted to obliterate most ostensible hints. This option could be a double-edge sword since on one hand, without any evident confession, the patient's humanity or even morality might become questionable. On the other hand, it seems favorable to one's social identity if the secret could remain untouched in the box.

To tell, or not to tell: that is a question. Goffman has categorized two kind of groups which may receive opprobrium: one is the "discredited", all discrepancies are clearly visible, the other is the "discreditable", bearing some scarcely apparent pejorative clues. Hence, while the disparaging waves are damaging to one's dignity and self-esteem, it seems reasonable for the members belonging to the second group to conceal their flaw. Besides, even among the fellow of the first group, under certain conditions, those who are different but with low "obstructiveness" could also meet the chance to pass the identity filter easily (Goffman, 2010).

Nevertheless, Goffman considered that those who carries the "discreditable" criterion sometimes will meet the circumstances of which it's preferable to disclose their disguised identity, thus, those who gone through the "passing" will have to deal with the identity crisis in front of the previously deceived interlocutors. The management of one's degraded status seems to be rather complex, according to Goffman, those who went through the stage of "passing" may eventually found the act unnecessary or unworthy, then spontaneously showcase their differences with a wholesome mental state.

Still, for the majority, those with visible differences may appear to be menacing or ominous, physically or morally. That may be the reason why the public might not expect the denigrated minority to be equate with or even surpass them. Surrounded mainly by the unhospitable entourage, Goffman underlined that those who reveal would usually face the dilemma of degrading themselves in a sarcastic manner ("minstrelization") or not doing so. Plus, the advices offered to the minority often stretch to the most somber room where the unspeakable objects sheltered, and pass through literatures and diagnoses, it seems to be a question of dualism since it may simultaneously divulge the blemishes of the marginals and ameliorate the living environment of them (Goffman, 2010). Another variation of minority consists of those who are untamed and do not submit themselves to the norm followed by the majority. It is believed that the members of this group find themselves unique in an outstanding manner, this "deviation" is then considered positive among themselves, yet their identities are still in danger and rejected when encountering the admirer of common social discipline (Goffman, 2010).

From the arguments above we may deduce that entanglement stressed on the ill and the minority could possibly be traced back to the public's untold aspiration, the savage side that should be surmounted and locked 
up through the process of civilization. Once being release, it would cause dread and shame. Additionally, there seems to be a difference between physical illness and mental illness: while the physical suffering such as cancer may unequivocally incarnate imprisoned lust, mental impairment appears to be a cunning tactician mingling with the startled public with unexpected swoops, targeted on their chained, ferocious, probably tabooed affection.

We may adduce Sontag's thesis again to justify that mental illness is of advantageous nature:

The romanticizing of madness reflects in the most vehement way the contemporary prestige of irrational or rude (spontaneous)

behavior (acting-out), of that very passionateness whose repression was once imaged to cause TB, and is now thought to cause cancer.

Consequently, one must not confuse somatic pain with psychical torment. But here comes other the questions: people possessing mental illness is still degraded since do not obey social rules, under what kind of circumstances would they obtain the dominance in a parole? Are there other crucial elements apart from revealing their mental state?

We can see that in Camus's The Stranger, Meursault was condemned to death not simply because he has ended a man's life, but also because of a series of seemingly ignorant comportments after his mother's death. The evidence can be found in the court, when Meursault's lawyer asked impatiently: "Eventually, is he accused of the burial of his mother or killing a man?" The public laughed ${ }^{20}$. Then the prosecutor retorted: "Yes, incontestably, I would accuse this man of attending a mother's burial with a heart of a criminal." This declaration appeared to take a considerable effect among the public ${ }^{21}$. It seems to be clear that a valid violation of convention requires a bilateral settlement. If an individual trespasses upon social norms and couldn't provide a persuasive explanation, then the public might not condone this violation. Disclosing one's sufferance seems to be one reason, but barely adequate, for that most illness are themselves an enigma, if not demystified, it would remain to be an incomprehensible deviance.

Given that the tuberculosis could be interpreted as the conversion of one's obsessional passion into delightful appearance at the expanse of one's life, and was thus embraced by the majority (Sontag, 2002), perhaps we can deduce that a more explicit defense related to human flaws or nature may have a chance to prevail in Meursault's story. Also, if TB uses the vitality to utter, the Asperger syndrome may have taken another pass to converse. Even more, the subject Meursault may have broached may be an intractable one, if it arouses public's vigilance and wind up their defense mechanism, it is reasonable that it would go straight to the process of catharsis. Ensuing these suppositions, the current essay will analyze the public's fear along with the unmentionable topics by employing the theories of "uncanny" and "abjection".

\subsection{Abjection and Uncanny}

Freud's doctrine of uncanny is also about the inhibition of will, triggered by some hints of childhood fantasy, that of taboos, malicious wishes, and self-centered worldview. Those thoughts were once abandoned and conquered, however, under particular circumstances, they will reappear and haunt people's mind. Freud's notice on Hoffmann's Sand Man is also worth discussing here, since it consists of a tale of delirium. To be concise, the story narrates a boy named Nathaniel, being frighten to madness after witnessing a serious of grotesque events, surrounding by elements of black magic, including: (1) a male lawyer who frequents the boy's home is alluded to snatch eyes and doing secret rituals with the boy's father, and (2) a man who sells "eyes", i.e. telescopes. Whenever the boy tries to peep, he would see either the lawyer or the salesman, then succumbs to the muddledness. The last time he glances through the telescope, was not long before his marriage; however, he was again possessed by illusions and after failing to push his girlfriend down, he pulled himself down the tower and crushed into fragments.

According to Freud's interpretation, the eyes can be considered as the stunt double of male genitalia, the concern of vision deprivation could imply the infantile fear of "castration", which may be stemmed from children's "Oedipus" wishes. Plus, the lawyer, i.e. the salesman and the sand-man who lingered in the boy's

\footnotetext{
${ }^{20}$ Original text: “«Enfin est-il accusé d'avoir enterré sa mère ou d'avoir tué un homme?» Le public a ri.".

${ }^{21}$ Original text: “«Oui, s'est-il écrié avec force, j’accuse cet homme d'avoir enterré une mère avec un cœur de criminel » Cette déclaration a paru faire un effet considérable sur le public.”.
} 
memory may potentially symbolize the father, who lurked around, waited to execute the punishment (Freud, 2003). Freud also clarified that the notion of a "doppelganger" was originally the emblem of oneself created to refuse the possibility of death, after the phase of self-center-ness it was replaced by the deadly omen, and progressively became a monitor of one's conduct i.e. the "conscience". Eventually, he asserted that the "uncanny" feeling to another self is related to the anabiosis ${ }^{22}$ of the previous faith toward oneself. If we read the Sand Man in a more dramatic but candid approach, the story may evoke something more than incest complex. Supposing that the father of Nathaniel was in a homosexual relationship with the lawyer, and the boy had bumped into a scene of ardor and heat despite the warning. It seems to explain why the impression had been clinging on the boy for a long period of time. And both the doll and the lawyer, could be seen as the mirror self of Nathaniel. One being torn up after the installation of the boy's eyes, the other kept emerging whenever Nathaniel surrenders to his curiosity or intends to start a relationship with girls, this might denote his passion for man. The death of the father could be also interpreted as a punishment of the disclosure of a taboo.

To decode the lexical meaning of "uncanny", one may start from the German word "heimlich", which means "homely", "tame", "familiar" (Freud, 2003), then, the word "unheimlich" signifies "what is concealed and kept hidden". Finally, the English version indicates the revelation of a formerly sheltered secret (Freud, 2003). Moreover, Freud's definition of uncanny consists of the liberation of inhibited narcissistic believes. Accordingly, we may state that the sense of "uncanny" is strictly tied-up with the mechanism of inhibition and punishment. We might also speculate that Nathaniel's sanity was destroyed by the coexistence the prohibited erotic fantasy, the observed trespassing in the family, and omnipresent discipline. The savage desire of the ancient epoque mixed with the painful lesson the human species had learned from the long continuum of socialization, along with the possibilities to get rid of the stranglehold... Nathaniel seemed to be at one time, the executor, the executed, and the fugitive advocator of wildness. The fact that the protagonist's perception has switched from bare eyes to the bought telescope might implies that there could be other people out there, desiring to become an eyewitness of something happening within a private space. The conflicts and climax of the tale principally took place inside of residences, and thrillingly, it was at the denouement, when Nathaniel observed the street, i.e. a public space, through the telescope and saw the lawyer, that the protagonist deceased. Crushed shortly after perceiving the error, his mirror self, slipped through the net of social decree walking openly on the street, his death could thus be ascribed to the overpowering sense regulation and lucidity. The feeling of "uncanny" may also be the fear of losing the restriction.

According to Kristeva, the creation of a new self is based on the death of the previous one, the one whose existence relies upon the remains of passion of one's parents: "“I" want none of that element, sign of their desire", and the "cadere" of the previous self will be accumulated with other unwanted fragments, later, become a standard to locate the new self, that standard is the "other". However, this undesired and demeaning other will keep lurking, and might invade anytime, to colonize one's subjectivity, therefore, all the trespassing is detestable since it alludes that the disciplines may not be as solid as it appears to be: "Any crime, because it draws attention to the fragility of the law..." (Kristeva, 1982). Moreover, this rejected self, seems to be the framework, used to discern humans in the "animal" word: "...to remove it from the threatening world of animals or animalism, which were imagined as representatives of sex and murder" (Kristeva, 1982). Furthermore, the "abject" seems to be "perverse" or "artistic", since it is able to manoeuvre the norms aptly (Kristeva, 1982). As a consequent, in the form of literature, it could finally be "release" under the cover of linguistic trap: "...literature may also involve not an ultimate resistance to but an unveiling of the abject: an elaboration, a discharge, and a hollowing out of abjection through the Crisis of the Word." (Kristeva, 1982), which allowed the banned and limited actions and impulsions to breathe again in an alternative manner (Kristeva, 1982). In The Stanger, Salamano and his dog's relation also seems to represent the consistent contradiction of the life: the dog always follows its wild instinct, and the owner responds to it with physical and verbal punishment (Camus, 2005). This necessity to control and to be out of control, like the necessity of keeping a domestic animal for company and restrict it, which may allude the need of banding other mirror selves, so that one can be assured nothing threatening will happen.

\footnotetext{
${ }^{22} \mathrm{~A}$ restoring to life from a dearthlike condition.
} 


\section{Results and Discussion}

\subsection{ADHD's role and artistic malapropism in ADHD is necessary}

The tale unfolds itself by an impressive ceremony, a scene to reward the best mothers with the residential permissions of the exclusive estate located in the city center. The mother of the protagonist, Yang Chuan, was invited as a special guest to give a speech on motherhood. Disturbingly, the scene picturing the enthusiasm for elitism was juxtaposed with a darker situation of which a doctor has diagnosed a large number of patients with "uppgivenhetssyndrom" 23 (ADHD is necessary 0:03:19-0:03:31). Similarly, on the stage, in the spotlight, while the mother referred to her successful son and stated affirmly "Only a mother who gets full credit can complete a child who gets perfect score" ( $A D H D$ is necessary 0:03:28-0:03:33), an audience in the dim light has broached the question of whether her daughter is as talented as her son, and the mother did not answer to it before a couple seconds of silence (ADHD is necessary 0:03:57-0:04:02).

In this highly competitive world, the symbols of power are omnipresent: flawless white outfits, minimalist estate with pure white interior decorations, and golden brooches are the rewards for the mothers who cultivate their children into elites; outfits that contains more than one color and the houses in lower conditions are the penalty for the mothers who failed, i.e. by the narration of the TV drama, whose children became blue-collar labors or criminals. Yang Chuan seemed to be a woman who is obsessed with power: long ago, when her son offered her a self-made key as a birthday present, and promised to build a tree house for her, she replied: "Mommy doesn't want nothing else but the golden brooch, that's what mommy really wanted, do you understand? So, don't waste your time on this, okay?", then she returned the key and left (ADHD is necessary $0: 35: 50-0: 37: 11)$.

On the other hand, Chuan's seemingly self-centered and stern character has a visible flaw, which contradicts but accomplishes her world of order, like the abject. This visible flaw is the symbolic, translucent, pale pink foulard she wore all the time. When her daughter Nova asked her "Do you wear it because it was a prize won by me?", she said: "I forgot, maybe it was so in the beginning, but it has been too long, and I have forgotten the reason" (ADHD is necessary 1:07:26-1:07:40). This pink foulard, being the only fabric that is not of the color white on Chuan's neat appearance, may symbolize the tie that links the mother with her unsuccessful daughter. As a reminder of the potential menace. It had fallen on the floor after Chuan's speech, when Chuan and Nova was bumped while surrounded by a crowed that rushed away because of the fear of "destruction", i.e. the punishment to the children with genetic defeats ( $A D H D$ is necessary 0:08:14-0:08:21). It was picked up by Nova, Chuan looked at it with a disturbed look and said "...look, it is smeared" (ADHD is necessary 0:09:190:09:24), Nova responded "I'll go wash it for you" (ADHD is necessary 0:09:24-0:09:27). Her action of cleaning the foulard could be associated with her latter choice of sacrificing herself to save her mother's reputation.

To preserve her mother's fame, Nova has gone through the process of tame and powerless to the untamed and powerful: she acted disruptively and aggressively in class (ADHD is necessary 0:21:27-0:21:52) and was successfully diagnosed with ADHD (ADHD is necessary 0:21:58-0:22:04), which is critical to save her mother's face, since this means the failure of the girl was not caused by educational problems. However, this act could also lead herself to the death. Yet, in spite of a chance to hide herself in the utopian shelter for the children with defeats (ADHD is necessary 1:02:27-1:02:39), Nova opted to walked out, and face the predictable death. Even it was at the cost of her life, under the disguised of ADHD, it seems to be a way how the timid girl had expressed her love and admiration to her mother. From her mother's perspective, Nova has also safe her own dignity by this decision, it could be deduced from the script follow: "You see, from the beginning till now, mommy has always kept you clean and tidy" (ADHD is necessary 1:10:15-1:10:25). And was declared in another scene: "Nova could have been destructed sooner or later for her bad grades, I did this to save her dignity" (ADHD is necessary 1:20:17-1:20:27). Plus, Nova's malapropism, her way to express love, also seemed to be accepted by her mother: when Nova asked: "Do you love me, mother?" Yang Chuan asked back: "do you love me?", Nova replied "I do". Chuan hugs her daughter: "Okay, then that's enough" (ADHD is necessary 1:16:35-1:17:18). We may read this dialog as: if Nova is ready to sacrifice for her, that's enough. By obtaining a concrete name of flaw, Nova, who seemed to be the abject of her proud mother had used the ADHD label to turn the tide, even, according to Yang Chuan both of them had prevented certain degree of hierarchical crisis. This may also justify that the mental illness is not completely pejorative. The aggressiveness is the malapropism to express her

\footnotetext{
${ }^{23}$ In Swedish. Resignation syndrome is a dissociative syndrome and this disorder mainly affects young people who have suffered psychological trauma.
} 
contradictory feeling of self-love and kinship-love, plus, the excessive actions going against the discipline could be read as the characteristic of the ADHD discourse in this piece.

\subsection{Bipolar disorder's role and artistic malapropism in Nothing Holds Back the Night}

The story is written in from a daughter's perspective, this daughter, haunted by her mother's suicide, began to write about her mother's life and tried to find out a reason for it (De Vigan, 2014). The epigraph of this novel has cited Pierre Soulages's words:

The differences in texture reflected more or less faintly the light, and a light emanated from the darkness, a pictorial light the emotional power of which stimulated my desire to paint. My instrument was no longer dark, but the secret light that came from the back. (De Vigan, 2014)

Her mother, Lucile is a very attractive woman, who has been a model in her youth (De Vigan, 2014). However, it is this lethal beauty that has posed her in a dangerous edged, accumulated with the death of her sunlines and parents, menacing her sanity and her will to survive, she once commented on her charm: "I was a very beautiful child and I paid a high price for it"(De Vigan, 2014), and another time: "I am a beautiful woman except that I have rotten teeth, which in a certain way I'm very pleased about, sometimes it even makes me laugh. I wanted it to be known that death lies beneath the surface" (De Vigan, 2014). The misery brought by the beauty also foreshadowed itself prematurely in her youth: "The way Georges looked at his daughter seemed full of surprise", "Lucile had intrigued him since she was very young" (De Vigan, 2014).

In Lucile's family, the paroles are often monopolized by the parents (De Vigan, 2014). Consequently, family stories seemed to have two version. One is the parent's official version, another is the version that spreads around by the younger generation. The latter is more frequently considered to be closer to the reality e.g. for Jean-Mark's death, version (1) "Jean-Mark had died in his sleep of asphyxia. He hadn't suffered. That was all they said", "Nothing must be said to other people. Jean-Mark was dead; there was nothing more to add" (De Vigan, 2014), version (2) "I discovered much later from Violette that Jean-Marc had died of hypoxyphilia, also known as autoerotic asphyxiation, in other words, during a masturbation session in which he was trying to enhance his orgasm through suffocation", "...Lisbeth told me...some knickers he had stolen from her..." (De Vigan, 2014). If one topic would have harmed the family's image, their parents will manage to conceal it. Therefore, when tempted to reveal her wounds, Lucile's words "... my father is watching me, he gives me sleeping pill and drags me into his bed. He raped me while I was asleep, I was sixteen, I have said it" (De Vigan, 2014) was muted by the collective silent of the family members. And finally, "Lucile retracted", "She denied her account of the act itself" (De Vigan, 2014).

Through this novel, the secrets inherently hidden under the splendor family image created by the writer's grandparents (De Vigan, 2014) have eventually meet the public. The depression, obsession, suicide, incest, anorexia, and anti-social tendency, self-injury, drug abuse, pilferage, and intermittent hallucinations which troubled Lucile till she deceased have regain their parole. Delphine, as a daughter of Lucile, had been a loyal audience and witness of her mother's malapropism, including Lucile's aggression on her sister Manon: "I screamed: "She's hitting her, she's hitting her!" I pressed the bell as hard as I could, shouted again" (De Vigan, 2014), "Lucile had wanted to put acupuncture needles in her eyes and had manage to insert one below her right eye", "Lucile was naked and painted white, looking crazed, her body shaking" (De Vigan, 2014). After her mother's death, and considering of the voice her mother tempted to utter in vain, Delphine seems to carry on her mother's will handed back the justice to her mother by divulging "Lucile was bipolar and it seems that incest is one of the factor which may trigger the condition" (De Vigan, 2014), adding with the statement of aunt Justine "This man who could have been content with being a wonderful father" (De Vigan, 2014). We may say that without the indication of the bipolar, the impact of this novel could have been far more mild, and, consequently, less persuasive. Also, the excessive moods going against the muted sound could be seen as the characteristic of the Bipolar discourse in this novel.

\subsection{Mental disease as a powerful metaphor}

Accordingly, if we come back to discuss Camus's The Stranger, we could justify that Meursault' actions are to be abject by the public since the violation of norms might awake the repressed self and intimidate the post- 
developed, civilized ego. Yet we may also interpret it this way, if we combine Kristeva's theory with the doctrines of Goffman, Sontag, and Freud: Meursault's singular utterances and incompatible conducts may be seen together as a highly artistic malapropism, endowed by the controversial stigma of mental disease. Although in regular circumstances it is deemed to be abject in light of its aggressive features and mysteriousness, once the encoded malapropism eventually be well read by its interlocutor, the former unpropitious elements might become propitious and appealing.

One major enigmatic malapropism presented in The Stranger is Meursault's action in the following day of his mother's burial. The public couldn't understand why he was able to go to the pool without showing a slightest trace of sorrow, even worse, he had past the night with an acquaintance he had previous lost contact and remarked in the pool (Camus, 2005). Nevertheless, they have ignored one crucial detail, while Meursault was in the water, and the girl was on the lifebuoy (Camus, 2005): "It felt good, and like making a joke, I let go my head, let it goes backward and posed it on her belly. She said nothing, and I have stayed this way" (Camus, $2005)^{24}$. This scene may symbolize Meursault's desire of being back to the womb, and his nostalgia for the chaotic state. Thus, if Meursault's overall characteristics had been defined as an autistic deportment, then the pool scene could have possibly been recognized as an artistic tribute, then be understood by the majority. Echoing Johnson's supposition on laughter the absence of a clear label, a concrete term to indicate, define, and demystify Meursault's malapropism, can be another reason why the story had failed to be a comical, or resonating work. If it meant to be one, the "signifier" should have been present, i.e. a possible image corresponding to the "signified" could be the Asperger syndrome. Hence, by accepting this label, the unique comportment going against the standard one could be regarded as the characteristic of the Asperger discourse in this novel. Unlike the Bipolar discourse mentioned above, the autistic emotions are subtle and preserved.

While the current paper focuses mainly on the clues in literature, researches in social studies also recorded the roses and thorns of mental impairments: Heilker and Yergeau have developed Corder's thesis and deployed the possibility of regarding Autistic repetition and self-conversation-exchanges as a rhetoric. They further encourage the interlocutors to perceive the mechanical parroting with creativity and be more inclusive when coming upon dialogic variations (Heilker \& Yergeau, 2011), such as the meaningful silence in language; Danforth and Navarro noticed that people's exclusion of ADHD may be due to the hyperactive individuals' disobedience, which is against conformity, i.e. lecturers seem to value the tamed over the untamed competitiveness (Danforth \& Navarro, 2001), the "disruptive" label of hyperactive learners (Danforth \& Navarro, 2001). On the other hand, their research also demonstrated the envious feeling of a young man: "...stated he wanted to be ADHD because then he would not have to turn his work in on time" (Danforth \& Navarro, 2001). The significance of this paper consists of its documentation, theorization, and reflection of social phenomenon on literatures, then provide another aspect on the linguistic role of mental diseases.

\subsection{The label and its power in language teaching}

The labels of mental illnesses are considered as the "signifier", the "signified" that the current article aims to refer are mainly the malapropisms, i.e. the variant discourses presented in verbal or nonverbal manners. While some may advocate voiding the words voiced by people with psychiatric disorders since they could be diagnosed as losing their ability to discern the truth in the hallucinations, those who believe in symbols and the unconscious like Freud or Lacan may still be capable to infer the verity from the given clues. Then, seek to read the repetitive, subtle, or significant deviances as the manifestations of their authentic will. Assuming that the rational people have already oriented themselves by following a discipline that rejects any visible yet natural savageness, consequently, the repressed sides are accumulating day by day: those deposit of thoughts and memories are imprisoned and fixed, like an obstinate wound, a drainless shower, or a body without excretory system. As we can simply deduce from the similes above, if the natural need deprivations are maintained intact, the individuals who failed to satisfy the natural demands in an alternative manner could be self-destructed at any moment. Poets and writers succeeded to alter by literary activities; dancers by their dances; painters by their paintings; musicians by their music. Others who didn't succeed may have been crushed and possessed by the loss of orientation due to their awareness of the overflowing deposits in themselves (Freud, 2003; Kristeva, 1982), then would have either ended up roaring through their somatic symptoms (Sontag, 2002), or howling through mental

${ }^{24}$ Original text: "Il faisait bon et, comme en plaisantant, j’ai laissé aller ma tête en arrière et je l'ai posée sur son ventre. Elle n’a rien dit et je suis resté ainsi". 
disorders. Hallucinations are like one's intro-quarrel, an internal conflict between the monitoring double and the disguised confession; deviant behaviors can also be interpreted as the disguised confession but the interlocutors are in the external world, i.e. they are the others.

However, a valid and effective pleading would require a comprehensible argument, and unlike the literary pieces which are often composed of accurate logic or opulent cultural hints, the artistic malapropisms seem to be more curious and enigmatic, thus, the decryption does not only require the entitlement of mental diseases, but also the spirt of and critical thinking and adventure, which could be valuable in language learning (Brown, 2014). Even though advocating the abject or the minor interpretation could be risky since it may harm one's dignity if the person is always seeking to be correct (Brown, 2014), making a practice of using self-challenging rhetoric could still be a commendable strategy to achieve a creative, or rebellious discourse, which is more close to the authentic, hidden meaning; like a fierce battle for releasing the inherent nature. Also, we may say that interpreting the unique comportment as a meaningful message, then translating it into linguistic rhetoric is like the process of concretization, progressively modifying the semantic sense of the biased lexis, this progress could echo with the minor approach perceived by Deleuze and Guattari, embedding one rule in another to breathe and to take effect. Hence, we could say that being aware of the possibilities of communications and keep challenging the established concept is indispensable for regaining the power. If the L2 learners are able to read and translate the malapropism or other taboo topics creatively and culturally, confront the contemporary bias against the minor discourses, and even being prepared to be the abject, they might be more confident and eloquent in the L2 debates.

\section{Conclusion and Suggestions}

Autistic person's major impairment rests on the socialization field, further ADHD, bipolar people also seemed to share the same flaw with them. The approach they use to converse is rare and can be easily misinterpreted. The paper began with analyzing the difficulties encountered by Meursault, and found out the obscure clues in verbal, gestural, environmental, and chronological hints. Followed by the theories about unconscious mind, reputation, socialization, and linguistic norms. Mental diseases presented in the two selected works seem to be both eloquent in their own manner of expressing, however, like in verbal discourses, a successful conversation requires the effort of both sides to complete. If your audience has hung up the phone and refused to read any message and letter, even worse, this person also avoided to see your face and block every possible contact, it is not easy to pass your message. This example might seem dramatic, yet it may be the situation that patients of mental impairments might be in, when he or she tries to converse in a singular and poetic manner, a stranger might be confused or even frighten away because of the unfamiliar, or "uncanny" feeling. The reason that this stranger is dreaded might be due to the fact that this kind of expression does not correspond with any culture he had learned previously, yet, by a direct instinct, this person somehow can catch the meaning. This non-coded message which is out of the order, has triggered the audience's mechanism of abjection. Like a call from the deepest mind, the audience hesitated to answer, fearing that he or she might be synchronized by it, and become a degraded being to the public. However, if the artistic side of mental disease is more frequently mentioned, the majority might start to listen and try to admire these authentic messages. Another critical point is, the applications of mental disorder as metaphor are important, since they embody the particularities of different artistic discourses, this help the majority to classify them, as though learning the syntax of an ancient language. In Meursault's case, we can observe the absence of this controversial metaphor, and we may conclude that, if the label were present, then it could had been a completely different story. In accordance with Goffman's perspective on the necessity of breaching the sheltered marks, the result indicates that it could be worthwhile to demonstrate this kind of labels, even if it might cause harm to oneself, revealing could also make the scar meaningful. The mental illness is thus, a Mark of Cain, frightening but protective. It provides a particular way to reasoning the hidden, repressed, unspeakable, and authentic emotion or cruel realities, then, makes the muted become voluble; pave the way for variant discourses.

Meanwhile, if the variant discourses are achievable through controversial metaphors in literary works, the application of taboo or singular lexis as a rhetoric could also be a powerful strategy in other genres. Especially in academic genres the debated terms are often muted and rarely connived. This fact could be lethal in the context of SLA since the learners of a second language are commonly taught to deport themselves more prudently and formally in another language. As a result, they might miss a creative process which the L1 learners could have gone through, i.e. uttering offensive expressions as an artistic malapropism in a humorous form in written or oral discourses. Being too cautious could not only limit learners' imagination and flexibility, but also 
decrease learners' motivation and deprive them of power. We may say that encouraging learners to use negative images as metaphors in the context of SLA can be a suitable start, and a necessary mission.

\section{References}

Brown, H. D. (2014). Principles of Language Learning and Teaching: A Course in Second Language Acquisition. Pearson Education.

Camus, A. (2005). L'étranger. (M. Korichi , \& A. Verlet, Eds.) Paris: Gallimard.

Danforth, S., \& Navarro, V. (2001). Hyper Talk: Sampling the Social Construction of ADHD in Everyday Language. Anthropology \& Education Quarterly, XXXII(2), 167-190. Retrieved from http://www.jstor.org/stable/3196091.

De Vigan, D. (2014). Nothing Holds Back the Night. (G. Miller, Trans.) Bloomsbury.

Freud, S. (2003). The Uncanny. (D. McLintoc, Trans.) Penguin.

Goffman, E. (2010). Stigma: Notes on the management of spoiled identity. (F.-T. Tseng, Trans.) Taipei: Socio Publishing.

Heilker, P., \& Yergeau, M. (2011). Autism and Rhetoric. College English, LXXIII(5), 485-497. Retrieved from http://www.jstor.org/stable/23052337.

Johnson, P. J. (1973). Bergson's Le Rire: Game Plan for Camus' L'Etranger? The French Review, XLVII(1), 46-56. Retrieved from http://www.jstor.org/stable/388006.

Kristeva, J. (1982). Powers of Horror: An Essay on Abjection. (L. S. Roudiez, Trans.) New York: Columbia University Press.

Li, S.-W., \& Lai, C.-Y. (2018, December 1). "Urine Field (Arrangement of Rice Field): Learning about Benign Prostatic Hyperplasia from One Song). Retrieved from www. youtube.com/watch?v=2P1y6ddRhYY

Liao, H.-J. (2019, January 18). Medical From Rice Field to Urine Field... Doctors Singing Out the Problem of Benign Prostatic Hyperplasia. Retrieved from Liberty Times Net: www.news.ltn.com.tw/news/life/breakingnews/2675632

Lu, G.-C. (2019, January 18). Introducing Benign Prostatic Hyperplasia: Arrangement of Jay Chou's Rice Field By Doctors in Hsinchu. Retrieved from Central News Agency: www.cna.com.tw/news/ahel/201901180171.aspx

McCarthy, P. (2004). Camus: The Stranger. New York: Cambridge University Press,. Retrieved from https://ebookcentral-proquestcom.ezproxy.lib.asia.edu.tw:2443/lib/asiatw/detail.action?docID=255211

Narlian, L. (2018, December 7). Lomepal : 4 Bonnes Raisons D'aimer Son Second Album 'Jeannine. Retrieved from franceinfo: https://www.francetvinfo.fr/culture/musique/rap/lomepal-4-bonnesraisons-d-aimer-son-second-album-jeannine_3303045.html

Searle, J. R. (1976). A Classification of Illocutionary Acts. Language in Society, V(1), 1-23. Retrieved from http://www.jstor.org/stable/4166848.

Sontag, S. (2002). Illness as Metaphor and AIDS and Its Metaphors. Penguin Books.

Valentinelli, P., \& Lomepal. (2018, December 7). Lomepal - Beau La Folie. Retrieved from https://genius.com/Lomepal-beau-la-folie-lyrics 